\title{
Digital Trends and Practice on the Hungarian Market
}

\author{
Katalin $\operatorname{Tari}^{1}$ \\ ${ }^{1}$ Doctoral School of Management and Social Sciences, Szent István University, Hungary, Gödöllő \\ Correspondence: Katalin Tari, Liliom street 25. HU-2040 Hungary, Budaörs. E-mail: katalintari@gmail.com
}

Received: January 22, 2020

Accepted: February 23, 2020 Online Published: February 28, 2020

doi:10.5539/ijms.v12n1p62

URL: https://doi.org/10.5539/ijms.v12n1p62

\begin{abstract}
As the implication of digital economy and the result of the technological innovation associated with change, new or transformed roles have been added to the online supply chain. The release of Industry 4.0 has brought about enormous changes, not only as regards to the increase of participants in the online marketplace, but also in terms of changing job responsibilities and job schedules.

Design/methodology/approach - This article defines the most important trends on the online markets based on faculty literatures, on e-commerce and e-marketing conferences and on in-depth interviews (qualitative research method) with Hungarian experts. Furthermore, the article outlines how difficult is it to include these processes for webshop operators, according to their experiences.

Findings - The article presents some results of e-commerce trends for which direction the online market might evolve and what sphere/division must focus on to exploit the opportunities of web. I tried to assess the difficulty of starting a new webshop during my research (on scale of 1-6). The innovative nature of the research is that it intends to illustrate Hungarian trends based on the processing of the professional literature of the subject.
\end{abstract}

Originality/value - Much of the discussion is based on Web 4.0 and Industry 4.0. This article pushes a few new and high priority trends and to suggest the evolution of the Internet with a reason which is based on future consumer society.

Keywords: digital trends, e-commerce, e-marketing, qualitative study

\section{Introduction}

\subsection{Introduce of Research Topic}

Reviewing the events of the past decades following the radical changes affecting the economy and thus the marketing sector, I am now experiencing a radical new digital era, also called the Golden Age of Digital Economy (Virányi, 2014). Even before the advent of the Golden Age it was written that certain factors have appreciated, such as commodity prices, proximity to consumer markets, and geographic integration as competitive factors. The modern information revolution has also had a profound effect on consumer behavior. It has been experienced in the past that Television has visibly influenced viewers' behavior patterns (Bögel, 2010). As regards to most interactive technologies this phenomenon is also present, however the internet makes us even more active and naturally leads to spending more money than its predecessor. It promotes the user to take actions such as searching, asking questions, informing other users and the manufacturer or seller and to express their opinions or providing feedback (Tari, 2017).

Just think of how much wider we need to estimate our competitors in the online market place-worldwide globally — in order to provide increasingly designable yet simple and user friendly web pages and blogs/posts. In addition to provide support for informative content marketing - concise designs, being user-friendly, and being to the point, are all essential to both-business and consumer sectors (Loveday \& Niehaus, 2008). All of this involves immense changes, hidden in the background as relating to job roles and within traditional supply chains.

\subsection{Literature Review}

\subsubsection{Evolution of Online Marketplace in Hungary}

Nowadays, it is hard to imagine but by the late 80 's the traditional American IT leaders (like IBM, Unisys, Wang, etc.) were all in trouble (Papows, 1999) as smaller, comparatively, highly focused hardware firms (like 3Com, 
Intel, Cisco, etc.) shall be able to stand up to the expected onslaught from Japan (like Hitachi, Fuji, Toshiba, etc.) or even these companies did withstand the Japanese assault. Although, fuelling this era of widespread anxiety were shifts in the performance of domestic IT markets all around the world. In Europe, IT spending averaged 14 per cent per year from 1986 until 1991, the American IT was only 7 per cent and the Japanese 16 per cent (Papows, 1999). It shows that the American IT sector was heavily online oriented but the technology gap was narrowing rapidly.

Most of the consumers were been familiar with brochures or other direct mails sent to their homes to present merchandise and solicit orders (Liu, 2018). In addition to enjoying convenient of in-home shopping and searching for unique, tailor-made item was normal from the 1990 in the U.S. and from the 2000 in Europe as well. At this time, there was some disadvantages for the consumers like higher prices (because of shipping), quality (have no experience to feel) or size (it does not fit to the buyer) because of incomplete information. Levenger (sells pens, decks, etc.) was the first one who sends consumers a postage-paid label (Peter \& Olson, 2005). Why was this idea so magnificent on the market? Those postage-paid labels were to return unwanted merchandise so it was able to reduce the risks of the potential consumers. Innovative solutions and improvement opportunities will always come into play of business' world.

It could be discovered interesting parallels in the virtual world from the 2000's from the first Hungarian websites and also the time-tested American websites. In parallel of the New York Times and The Wall Street Journal appearing online so did the Figyelö, HVG.hu and FrissHirek.hu in Hungary. Visitors to these websites in the early 2000's could already customize the content they wanted to see on the websites.

An overwhelming majority of visitors to virtual platforms/websites eventually became regular internet users. There are a number of publications on the penetration of world-wide internet usage among, which MINIWATTS Marketing Group (2018) compiled and published a study on "internetworldstats.com" (on the basis of population and internet users on a given continent, as well as the percentage of this in comparison to the world population). According to this worldwide survey, which showed an average increase of $1.066 \%$ throughout the years of 2000-2018? In proportion to the internet users that showed an increase was mainly in Africa of $10.19 \%$ and in the Middle East of $4.89 \%$. Since it was not specified in the survey regarding Hungarian internet penetration geographically, I therefore compared the survey with the 2018 data of KSH (Hungarian Central Statistical Office is in Hungarian "Központi Statisztikai Hivatal" as KSH, 2018). In comparison regards to the KSH (2018) EU-28 data of $83 \%$ and MINIWATTS (2018) combined European data of $85.2 \%$ (without significant deviation), I also present the results for Hungary. Hungary is at $76 \%$ internet penetration and the world average is $55.1 \%$.

Not all internet users buy online, so the number of customers in the virtual marketplace is also an important consideration. This value in Hungary is 3 million persons ( $\mathrm{KSH}, 2018$ ).

The number of internet users compared to the EU average of $65 \%$ and Hungarian average of $45 \%$ internet users are considerably less.

Looking further, into the macroeconomics backgrounds of the two countries, are participating in a study, according to the publication of the Ministry for Economic Affairs. In 2001, USA was already the third largest direct investor to Hungary with the amount of $€ 238.5$ million ( $\$ 257.44$ million, calculated in February of 2020). USA is currently the second largest investor to Hungary with nearly $€ 14.5$ billion ( $\$ 15.65$ billion), furthermore is the first export partner outside of the EU.

Companies operating in Hungary, but are owned by USA companies employed over 93,000 persons. Due to low wages and activities that can be outsourced can be relocated to developing countries; therefore, the economic cooperation between the two countries is increasingly gaining ground. In contrast it must be noted that the study from PORTFOLIO (2018) which states that the USA needs to cope with its growing debt. The two countries economic partnerships or rather after the Industry 4.0 expansion a noticeable economic transformation has occurred and in particular and also had a major impact on the food industry too.

It should be noted that from the stand point of e-commerce retail sales (as well as the number of participants) increased significantly in 2015. Online purchases accounted for $2.5 \%$ of all retail sales in Hungary, which amount to 229 billion HUF and since 2010 an increase of $38 \%$ is recorded on average every year compared to the previous year.

Knoke and Kovács (2018) mention as well that the internet may wipe out or create new business models, as it delivers opportunities into filling potential gapes in retail, meanwhile large corporations are rewarded by expanding their network and surpass thresholds, which may in turn lead to large monopolies to be formed.

Innovation solutions and new development trends ascertain increased importance to both the micro and 
macroeconomic level. According to a study by IVSZ (2017) with the introduction of Industry 4.0 and in the world of digitization there is an increase in and special attention is promoted on behalf of state sponsored aid. Compared to previous years and increase of funds and financial recourses are attributed to related software and applications of digitization.

\subsubsection{E-Commerce or E-Business?}

Several definitions are known within the literature to define the two concepts and from these I will present some relevant ones. These two terms are often used interchangeably, although e-business, which means the whole business management system, already includes e-commerce - this includes online marketing, sales, logistics, provide customers information and everything else related to the world wide web and making money through it (Tari, 2017).

E-business also includes internal operations such as manufacturing, inventory management, product development, risk management, finance, knowledge management or human resources (Fejlesztokhaza.hu, 2001).

E-commerce was introduced worldwide in the early 1990s and it emerged in Hungary shortly after the turn of the millennium. From the middle of 2000s, it has shown very rapid development and it continues unhindered today even more.

E-commerce is big business that is dynamical increasing day by day. According to a report from eMarketers', business consumers (B2C) e-commerce sales worldwide could reach $\$ 1.5$ trillion in 2014, up nearly 20 percent from 2013 (Nielsen, 2014).

E-commerce or electronic commerce is a modern business methodology that addresses the needs of business organizations, where the sellers and consumers reduce prices while improving the quality of products and services, and while achieving faster delivery (Tutorials Point, 2014).

"E-commerce is the online support associated with a series of transactions between buyer, seller and business partners and their immediate environment. E-business covers strategy-building, management issues, and in general includes and covers technological-related innovation capacities" (Nemeslaki, 2004).

\subsubsection{E-Business: Factors of the E-Market}

The introduction of e-commerce actors is not the scope of this article. Even so, I still need to introduce some of them to make the topic coherent.

E-commerce operators are divided into three categories by the e-commerce $\mathrm{ABC}$ : government agencies as in e-Administration, and corporate as in e-Business, and lastly the consumer as in e-Consumer (Nemeslaki, 2004).

Based on the relationship between sellers and buyers, online commerce can be divided into four basic sub-markets. According to their economic role, the following:

- Business-to-Business (B2B),

- Business-to-Customer (B2C),

- Customer/consumer-to-Customer (C2C),

- Business-to-Administration/Government (B2A; B2G) (Bányai \& Novák, 2015).

EU reports on E-business W@tch (2005) include data collected from 2002 on the use of e-business by small and medium-sized enterprises (SME's). After the surveys and the analysis of the research questionnaire of the ICT of each industrial sector, that is, the application of Information and Communication Technologies regarding e-business, and these business practices are summarized and determined by three factors. These are referred to as e-readiness (1), e-activity (2), and e-impact (3). In a short summary, e-readiness highlights differences between countries comparing the organizational capabilities/readiness of their countries' Information and Communication Technology (ICT) infrastructure, their governments, their citizens, and their businesses, with the potential for sustainable development in mind. E-activity is an analysis designed to analyze integrated e-business processes. Evaluates automated electronic internal and external business (B2B and B2C) processes. Includes the internal processes for resources, procurement, elements of internal and external logistics, production, marketing and sales. External e-activity, compares opportunities for collaboration which may include additional business partners or a third party in the countries (B2B, B2C, B2G). The third factor is called e-impact, which in a short summary is rather complicated, since during the process the so called "effective profit" is observed/examined. More precisely defined it means the utility-businesses including the self-employed have applied, in the practical world of e-business, it further examines the effects and changes in the industry and the policies/politics of a specific country. 
Valenduc and Vendramin (2016) mentioned as an essential aspect the clarification of new and/or transformed jobs and the securing of the workforce behind these transformed supply chain processes. To perform the tasks mentioned above many - new or transformed small and medium-sized enterprises have been or are still being created. As a result, small and medium-sized businesses as well as large companies tend to outsource certain jobs for more efficient operation (e.g. -web site management and design, graphic work, marketing campaigns, etc.). The research also points out that the robotization opportunity of the workflows not only enables and allows for more accurate work and scheduling, but it also results in freeing up human labor, whom are removed from monotonous workflow jobs (e.g. -sending Postage paid for (letters), running automated advertisements, etc.). They are recruited as part-time labor by companies from across the globe if they are more efficient, so they can work for several companies as sole proprietors/self-employed or by contract so that they may spend more time with their families (e.g. -parents on maternity leave).

\subsubsection{E-Marketing}

In the world of marketing campaigns - in our case, online marketing in particular - innovative solutions, rapid responses to change and new development opportunities are more competitive than ever. Since information flows faster than ever it helps your business, reach a larger target audience. However, at the same time this information contains uncertainty arising from variation in data and consumer behavior trends (Syed, 2018). In addition, with the proper positioning and segmentation of the target market, with the use of correctly designed sales promotions, the use of differentiated pricing and product policies are among the most common means of efficiency (Ryan, 2014). They play as much role in improving competitiveness as they do consumer satisfaction.

It is a competitive advantage and helps to target the consumers needs more effectively when companies that are online conduct analysis or have it outsourced. A logged in account can help you to track consumers for the use of your products and/or services, by analyzing your browser data (country, language usage), browsing history, search results (Fehér, 2013). The primary tools for building consumer confidence in Hungary are attributed to the following: flexible opening hours, comparative prices, have a large selection in their product range, the principle of simple wording, but immediately followed up by an accurate description, the ease of use with non-problematic applications to be used by smart phones users (Shoprenter, 2016; Langmar, 2016; Laudon \& Traver, 2015).

\subsubsection{Digital Consumer}

It is vitally important to distinguish the target group from right from the start. Internet surfers can be divided into two main groups based on their relationship with e-commerce. The group, that does not purchase and the other group are the ones that do conduct purchases online and therefore are direct participants of the economy. While the numbers of internet users are indicating slow growth, online consumer users are gradually increasing (Laudon \& Traver, 2015).

According to various research, there is no more attentive audience than the online consumer who is constantly searching for information are convinced by facts and reasoning, and the classic methods of brand advertising leave them cold (Fehér, 2016; Sadowski, 2000). The McKinsey consulting firm has divided the online consumers involved in its research into six separate clusters. Simplifiers account for $29 \%$ of active users and account for more than half of online purchases. Communicators $(36 \%)$ primarily use the internet for communication. Routine users (15\%) search for thematic content and use a site of interest where they spend $80 \%$ of their time online. Surfers $(8 \%)$ spend most of their time on the Internet and it is difficult to make them brand loyal. Negotiators (8\%) spend most of their browsing time on online auction sites such as eBay. While browsing not only do they find good value for their money, they also provide their opinions to virtual communities. The sixth group is athletes (4\%), who spend their time online primarily discovering content related to sports and entertainment (Forsyth, 2000; Eszes \& Bányai, 2002; Eszes, 2011).

\subsubsection{Online Consumer Behaviour}

Consumer centered thinking prevails in the digital space and therefore personalization of the product, services and advertising appear at these levels. According to Eszes and Bányai (2002), customers may want not only services that they may find on another website, but also services that they may envision. The consumer may develop and shapes the product and/or service according to their specific needs, ideas or desires. Therefore, the consumer gains in part or has full control of the marketing function. Meanwhile, Amazon is already optimizing its sales so that it may be flexiable, speedy and rationally serve the needs and expectations of the customer and brings about the store model of 1-1 without sales personeel, with the aid of machines/robots and is fully automated. Further, if consumer behavior is not properly gauged there is a possibility it may hurt firm's profitability (Javed, 2015). Here, in Hungary for the most part and for the time being, these solutions are only 
supplementing or replacing the usual processes for buying a product. There, as exhibit first in Table 1 shows four strategies for consumers to make exchanges involving these two modes, purchasing and shopping. Consumers can both, so shop and purchase electronically (as she or he order a book or a CD from Amazon). In the first case, the entire shopping and purchasing sequence is done electronically. Another strategy, as the consumers can use is the store-aided e-exchange. In this case, consumers shop at the store first to examine and experience some products from the company. After, as she or he knows which stuff want to buy, they go home and purchase the product online. The third strategy, as consumers can use involves collecting information online and then going to a brick-and-mortar store or dealer/jobber to have a purchase. Moreover, consumers can shop and purchase 'clear' in the store without using the Internet at all.

Table 1. Point-and-click and brick-and-mortar consumer strategies

\begin{tabular}{llll}
\hline PURCHASING & & SHOPPING & \\
\cline { 3 - 4 } & & Online & In-store \\
\cline { 2 - 4 } & Online & Electronic Exchange & Store-aided \\
& & & Electronic Exchange \\
& \multirow{2}{*}{ In-store } & Web-aided & Traditional Exchange \\
& & Store Exchange & \\
\hline
\end{tabular}

Source: Peter-Olson, 2005, p. 503.

As to the aspects of decisions as regards to online purchases, I should mention Technology Acceptance Model (TAM), which points to the following aspects: the response/adaption to technology, positive user attitude and the possibility for promoting user confidence. The Characteristics of the Online Consumer is based upon and first summarized in the original compiled Customer Style Inventory (CSI). Of the defined original 8 factors, 7 were identified and can be found in the online marketplace. These online consumers strive for quality and are based upon brand loyalty, fashion, product portability, website content and design.

In the search of consumer influencing behaviours the study finds many definitions for these factors. On the level of micro economics, the following conditions are driving factors, these are economical, political, legal, technological, infrastructural and also cultural. In addition, to personal preferences, personality traits and circumstances that influence the consumer on the contested factors. According to the Marketing Communication Handbook, the manufacturer's incentives for the consumer are to test and promote the brand name for the user. The promotion of the company and brand name, and the encouragement of sales are now considered two separate marketing goals for, which any online platform or social media may be its medium. In as regards to the consumer's behavior and that the consumption patterns of Hungarian households are influenced by several factors.

\subsection{Hypotheses}

\subsubsection{First Hypotheses (H1)}

According to professional web experts, it is relatively easy to enter the Hungarian online market with a new online store (regardless of sector).

\subsubsection{Second Hypotheses (H2)}

The prerequisite for a successful and long-term operation of a new web store is not only the promotion of a consumer-oriented product and/or services in the online marketplace. Proper timing and adequate capital are also required and is an essential aspect to be competitive with maximum efficiency.

\subsubsection{First Aim}

Mapping online marketing and e-commerce trends with eye of experts.

\subsubsection{Second Target}

E-marketing trends compared with Hungary and worldwide (megatrends).

\section{Method}

\subsection{Identify Subsections}

The further expansion of this research under investigation was facilitated by a qualitative procedure and with the aid of semi-standardized in-depth interviews. The results are based on content analysis of the interviews. The interviewees switched from the offline marketplace, but the interviewees were professionals working in the 
online marketplace. Their activities concern the banking, legal, logistics and freight sectors, marketing, as well as advertising agencies and search engine optimization divisions. Sampling was random however the largest and best-known companies were contacted. The participants of the survey requested to remain anonymous. The content analysis was done by using a demo version of NVivo to produce the results.

In addition to modeling, I evaluated the complexity of launching a new webshop in practice and the results of the in-depth interview subjects were answered on a scale of 1-6. I did not quantify these results, but defined them as qualitative criteria such as "1" meaning: it is a very simple task to enter the online market with a new company in Hungary, and "6" meaning: for a new emerging company it is very difficult in the Hungarian online market.

This research is a pretest in nature and non-representative, but will be primarily used as a guide for the preparation of my subsequent research and dissertation.

\subsection{Characteristics of the Sample}

This chapter shows the analysis of the demographic background of the sample $(\mathrm{N}=10$ people). The average age of the professionals interviewed is around 34 years of age. My oldest respondent was 44 and the youngest was 26 years old. All interview subjects have a university degree in economics of which of them have 4 have university and 6 college degrees. With the exception of 2 persons - who also live within a city of Pest County - the surveyed professionals ( 8 persons) live in the capital, Budapest. During my in-depth interviews, my subjects were 5 female and 5 male respondents.

\subsection{Sampling Procedures}

Anonymity was requested by the subjects, so I omitted the insertion of the summary table with reference to the small number of items, but the significant information is explained below (position, work experience, scope of activity). They all have middle or senior management positions and have had at least 3 years experience to a maximum of 18 years experience. In terms of their activities several business sectors were selected (deliberately). Their activities include providing logistical background, there were those that design, lead, and track marketing and/or creative campaigns (with statistical analysis), or those that fully service an online web-store, retarget, optimization services, or provide online legal advice.

\section{Results}

In this chapter, hypotheses will be answered and several Hungarian digital marketing and e-commerce trends are introduced, based on the analysis of the literature and interviews of the experts. Furthermore, these will offer the readers answers to how complicated is it to operate a web shop in practice (on a scale of $1-6$, where 1 is the easiest, 5 is the most difficult)?

\subsection{Summary Results of the Practical Side: Analysis of Professional In-Depth Interviews}

It was communicated to each of my respondents that whether you are either serving the business or the consumer sector, it is essential that your online advertising and optimization techniques be supported with offline activities for your company's campaign. In order for a company to be successful in the long run, both online and offline operations are important in the Hungarian markets (regardless of the sector). Because of this, and because of smaller and more rapid changes in a company's infrastructure, the opportunities offered by the wings of the automated world in Hungary are unfolding slowly. The potential for crossing geographical boundaries has almost been discovered as an opportunity in the Hungarian market, as considered to overseas, and with reference to job-related changes described in the literature-however, there is still plenty of room for improvement. All ten professionals have set the time interval between 8-10 years for Hungary to be technologically, socially and economically open to an independent online marketplace where you can shop comfortably. Though the Hungarian consumer is opening up to the advancement of technology it is still far for the Hungarian consumer to accept and is only slowly coming into our daily lives, however, in order to operate efficiently, the outsourcing of certain activities is supported by the domestic market. All ten respondents supported the idea that the company would be more efficient by outsourcing larger, more important activities, such as managing ads, running a website, or graphic design. Regarding these roles/activities, work from home and part-time work has appeared in these areas of professions. When crossing geographic boundaries, only one respondent highlighted the involvement of customer support staff, a task that is already popular in the United States for outsourcing (India and Hungary, e.g., -are among the first in the IT sector).

My respondents have identified a number of conditions for a new online shop to enter the Hungarian market, which I will elaborate on from the responses of my second hypothesis. In a nutshell, personalized products and/or services, timing and the availability of a sufficient amount of capital are only the basis for a successful and stable operation of a company in the Hungarian market. In addition, a number of factors are needed to keep a 
company going for decades.

\subsection{Answered Hypotheses and Questions}

\subsubsection{First Hypotheses (H1)}

According to professional web experts, it is relatively easy to enter the Hungarian online market with a new online store (regardless of sector).

I accepted this hypothesis because of the subjects of the in-depth interviews were able to answer on a scale of 1-6. I did not quantify these results, but defined them as qualitative criteria such as "1" meaning: it is a very simple task to enter the online market with a new company in Hungary, and " 6 " meaning: for a new emerging company it is very difficult in the Hungarian online market. In the analysis of the ten interviews, one person responded with a 2 and all my other respondents responded with 1, thus, considered entering the online market as a very simple task.

When examining the hypothesis, they all mentioned the existence of adequate capital, that if there is no adequate capital, the difficulty of entering the market will be encumbered. Accessing the "online market in Hungary" is which seemed to them to be questionable and rather cumbersome, since companies can reach more and more consumers abroad. In-depth interviews with marketing agency staff have revealed that they are currently able to serve "any industry sector," but if they cannot, they can solve problematic situations with the appropriate level of social connections/capital. So, the right capital is not just financial, but also intellectual and relationship-based capital. My seventh interviewee works with 12 people at a company that has been in business for over 15 years. $\mathrm{He}$ also promotes referrals or even works with other companies to achieve their common marketing goals, tailored to the customer's requirements. Thus, an important factor is trust that has emerged among professionals over the years through the joint projects. In the case of online marketing campaigns, the best investment opportunities can be lost if they are not timed correctly, positioned, or segmented. So, the most popular trends in the Hungarian online market are personalized offers and thematic online materials. In addition, it has been said that proper use and application of content marketing can increase our reach as well as search engine optimization - such as blogging, blog post promotion, guest blogging, etc.

Also, in the offline field, I have a homogeneous result with regard to B2B marketing, typically with the selection of channels used in practice, so online without offline does not work effectively when it comes to sales, only when it comes to reputation building. Thus, attending online conferences and giving professional presentations, for example. Conversion World - they have become typical efficiency enhancing tool. In association to the professional magazines interviewed, among the companies I interviewed also placed great emphasis on article publishing and advertising opportunities. The use of these two offline channels to widen both your corporate reputation and your customer base is definitively decisive action.

\subsubsection{Second Hypotheses (H2)}

The prerequisite for a successful and long-term operation of a new web store is not only the promotion of a consumer-oriented product and/or services for the online marketplace. Another essential aspect to be competitive with maximum efficiency, good timing and adequate capital are also required.

I rejected my second hypothesis as there are many other factors that would make it feasible. The first hypothesis also included the concept of capital (for example), which covers not only financial but also intellectual and relationship capital.

The answers to the second hypothesis could be divided into two groups based on what was said in each by the in-depth interview subjects and what they did not. Firstly, to replace personal contact after online activities. One of the tools to support online activities is, for example, the thorough and rapid work of the customer service or active participation in professional conferences. They all found it very important to be able as a speaker to present their company and it's potential. Within the corporate sphere a typical customer acquisition method mentioned is through tendering, which is also based on personal relationships. The other group, I mainly focused on covers the business of B2B trade. This is where the offline activities are grouped around education: training, newspaper appearances such as articles, reports or case studies, etc. - or the possibility of personal consulting. Part of it belongs here and that is the opportunity to attend conferences, provided that they are of an educational nature and present an analysis of their activities. The results of the survey are not representative due to low number count and composition of the elements.

One of the most important elements of building an optimal and efficient online business is analyzing statistical data which I will discuss, and which inadvertently disclose information about a webshop or website visitor, such as: Google, or your Gmail account, social networking profile, etc. — that is logged in and interprets the statistics 
of our browser and our browsing history - these activities are closely related factors influencing each other's results. If I properly interpret the statistics available of our website visitors, our efficiency and reach will also increase and help strengthen our competitiveness.

These are referred to as conversion factors by professionals and stated in the literature. The external (uniqueness, availability, seasonality, etc.) and internal (usability, informative, comprehensible, etc.) conversion factors affect the effectiveness of the communication channel, therefore by considering and analyzing them they increase the efficiency of the web pages. Also included is the possibility that even a moment of joy or mood change may trigger two different reactions from one person when you visit website, even as an employee of the website.

Effective positioning and segmentation, as mentioned above, with the appropriate professional knowledge for business-to-business members is essential for efficiency. If you want to reach consumers directly as a web shop operator, you should still seek the advice or control of a professional online marketer to ensure you are successful.

It is also important that in addition to optimal timing, product policy, competitors, emerging online trends, and sales promotions in line with the above should also be considered.

In order to make this work so well, the agencies are using analytical programs that, while surfing the web not only monitor, analyze, but infer possible outcomes, future purchase decisions - the vast majority of those surveyed said, that is for the 5 people - as persons 1, 2, 5, 6, 7 responded. The program is based on sophisticated system theory, which is constantly evolving. The goal of the analytics programs is to optimize and improve efficiency, and thus to enhance competitiveness.

\subsection{E-Marketing Trends in Hungary and Worldwide (Megatrends)}

In the competitive selection of online marketing strategies, good positioning has become more and more appreciated year after year, and the concepts for proper segmentation of such. After determining, which online consumers would like to target the company with their products, it is an important aspect to find who is influencing the online market and winning their approval and being able to implement their vision will be more widespread in the 2019 campaigns. While there are great innovations in robotics and that robots will soar explosively in industry, however it will take a few years for this trend to reach the average consumer. It will be a key part of 2019 marketing plans to further develop and improve applications and to implement more questionnaires into these systems so that demographic characteristics can be analyzed so that the company may better position ourselves to our consumers behaviour and habits. This was a highlight in October 2019, in a course of Google. A computer, laptop or telephone may be used by more than one individual within a family, however for the purpose of using applications for sports or losing weight it is not. It is important to stay clear in mind so from old subcultures new user bases are emerging, which may mean new markets on the horizon. It is enough to think of the 10 years old boy applying makeup on Instagram (for example: think of "makeupbyjack"). The online market may converge both horizontally and vertically, but new potential market gaps may emerge. In regards to the $\mathrm{B} 2 \mathrm{~B}$ sector gaining in automated processes and further innovations present possibilities, which not only hold new possibilities, but can change job definitions and may create the options for new tools and equipment.

Researching e-commerce trends offers many opportunities for all participants of the online market to engage in and things to contemplate. As a member of the information society, it will be produced new patterns of behavior, all while knowledge and preparedness becomes faster because almost everyone uses a smart phone. From the corporate point of view, it appears as intellectual capital that influences competitiveness, but this is superficial and runs counter to a number of traditional corporate governance principles such as hierarchy, chain of command, respect, stability, bureaucracy and sphere of authority/competences (Bőgel, 2010). The proper positioning of consumer markets is still prominent in ensuring increased competitiveness (Javed, 2015; Sadowski, 2000). In 2020, winning over the influencer's is an additional instrument that affects the market.

Nowadays, a smart idea can easily make millions for our company, but our stability can easily be derailed by a negative wave of opinions being disseminated online (Laudon \& Traver, 2015).

Another trend, that came out at the end of 2016, built with the aforementioned functionality and by capturing a personal position, forged a competitive edge in relation to search engines. The services that have been created by products of Amazon and Apple's "Siri" software-where you can dictate, ask questions, express opinions, listen to music, get information, etc., and it all can be done by just saying a few words. The time spent during dictation is reduced, more over comfort and the sense of usefulness is satisfied. Using words that are fast and simple, our machines and our phones can search for anything what consumer want (from the weather, through the nearest 
restaurant to music), or call for us instead (Tari, 2016).

Another influencing factor is the automation which in the development of applications appears at the e-commerce consumer level, where customer provide more and more accurate information about ourselves (e.g., in an exercise program: gender, age, weight, height, frequency of exercise, etc.). With the data you provide during the use of these applications, segmentation will be even more accurate and simple. There is a similar megatrend at a national level for each nation, which is that consumers need to be properly segmented to ensure, so they can be accurately reached and personalized regarding each campaign. The distribution of human resources may be transformed, or maybe even eliminated entirely due to automation. Robotization and automation varies from one nation to another, but is receiving more attention from year to year (Tari, 2017). As regards to the possibilities for innovation, research \& development, and for the development of robotics there is no limit to national co-operation, this in turn will result in significantly increasing the degree of integration of horizontal and vertical markets.

In 2020, those online or half online companies can make a large advantage who's are going to invest into automatizaton (software) or into the robotics (hardware and software). At the e-consumer end the automatization shows up in the evolution of the applications, which based on our more specific answers (for example in training apps consumer give them gender, age, weight, height or the frequentness of body work). With all of the informations are being given at the app, the segmentation (or personalization) is getting better and easier. The national consistency is to isolate the consumer when a more personalized and reliable goal comes to a halt during a campaign. The level of robotization varies from one nation to another, but it has received increasing attention in recent years.

Digital trends have a significant impact on social and on environmental sectors as well. On one hand, socially diversifying and developing education can help promote healthy lifestyles, for example such as sports, water and food consumption (Jamsheer, 2019), as well as automated few jobs and workplace tasks (Tari, 2016). Other social and environmental changes include energy savings and time efficiency. In this context, sustainability continues to play a key role in the e-market (Tiwari, 2011). Online media often does not substitute rather it supplements for print media, thus increasing environmental impacts. Therefore, there is a risk of cumulative effects and incomplete substitution (Fichter, 2001). More important factors influencing the environmental effects of Internet use and e-business are: frequency and duration of media use, degree of utilization of individual devices/media (differences between professional and private sector), multipurpose of the devices/media and utilization behaviours/forms (Fichter, 2001). The environmental and social points of view have brought digital economy about comparability of prices, product offerings, Virtual Reality, Augmented Reality, thereby stimulating competition. In many cases, this also leads to an improvement in the quality of service (Fichter, 2001). The inclusion of shipping costs in the price, coupon offers and (beauty) box promotions are gaining popularity in the Central European market.

The international cooperation of innovation, research and development and also in the robotics held no borders (Damian, 2014). This will raise the numbers of the merging of the horizontal and vertical market in 2020. The perfect positioning of the consumer market is still the most important because it gives a big advantage in competitiveness. In 2020, it's focused on winning the influencers and the other marketing opportunities.

In the processing of this current questionnaire and completing this study I have found new research topics to be implemented in the future. First of all, I would like emphases, online market guidelines for the differences by country and online consumer habits would be another focus. Another research topic that was born from the research of this study would affect logistics, jobs, personal contacts and the development of communication tools.

In the future, the online marketplace will certainly continue to grow and the possibilities full of new technologies, strategies and user-friendly equipment need to be tested and should be analyzed before larger amounts of capital are injected in the project. It is for this reason or rather my goal as to recommend further research topics to better my professional development in topics that are innovative and current.

\section{Discussion}

By conducting the research, I aimed to highlight the changes and possible future outcomes that will determine the life of the digital economy, and to some extent allowing market players to be prepared for innovations, changes and innovative solutions from across different channels.

One of the aims of my present thesis was to search for new, innovative, efficiency-enhancing opportunities and research these tools, to estimate the volume of their efficiency and reliability, and to present the business trends 
used in practice on the Hungarian markets.

Furthermore, the aim of my study was to illustrate our effective corporate operations in Hungary, the barriers to online entry in practice, and highPlease check the subheading.light the continued success of combined (online and offline) campaigns.

Industry 4.0 is taking into account the changes in work processes that are gaining ground, in order to maintain competitiveness and increase efficiency, I emphasized that human must first learn to work with each other through remote working relationships, and then to be able work with robots in the future.

After completing the current phase of the study, I believe that the topic of the online market still has many hidden research alternatives and opportunities and that is why I have already begun to reach out online to potential interviewees to expand my research.

Among my future research plans are to include in-depth analysis between two nations (American and Hungarian) and to further my research as such.

\section{References}

Bányai, E., \& Novák, P. (2015). Online üzlet és marketing (pp. 91-93). Budapest, Akadémiai Kiadó. https://doi.org/10.1556/9789630597258

Bőgel, G. (2010). Verseny az elektronikus üzletben (pp. 12-41). Budapest, Műszaki Könyvkiadó.

Damian, R. (2014). Understanding digital marketing, marketing strategies for engaging the digital generation (pp. 34-409). London: Kogan Page. ISBN: 978-0-7494-71-02-6.

Eszes, I. (2011). Digitális gazdaság-Az e-kereskedelem marketinges szemmel. Budapest: Nemzeti Tankönyvkiadó.

Eszes, I., \& Bányai, E. (2002). Online marketing. Budapest: Akadémiai Kiadó.

Fehér, A., Soós, M., \& Szakály, Z. (2014). Az élelmiszer-fogyasztói magatartás vizsgálata online környezetben: Létezik-e hazánkban digitális élelmiszer fogyasztó? Táplálkozásmarketing, 1(1-2), 29-38. Retrieved from http://taplalkozasmarketing.com/wp-content/uploads/03_Feh\%C3\%A9r-A.-\%E2\%80\%93-So\%C3\%B3s-M. -\%E2\%80\%93-Szak\%C3\%A1ly-Z._Az-\%C3\%A9lelmiszer-fogyaszt $\% \mathrm{C} 3 \% \mathrm{~B} 3 \mathrm{C}$-magatart $\% \mathrm{C} 3 \% \mathrm{~A} 1 \mathrm{~s}$-vizsg $\% \mathrm{C} 3 \% \mathrm{~A} 1$ lata-online-k\%C3\%B6rnyezetben_L\%C3\%A9tezik-e-haz $\% \mathrm{C} 3 \% \mathrm{~A} 1$ nkban-digit\%C3\%A1lis-\%C3 $\%$ A9lelmiszerfogyaszt $\% \mathrm{C} 3 \% \mathrm{~B} 3 . p d f$

Fejlesztők, H. (2001). Webhop. Retrieved from http://fejlesztokhaza.hu/szolgaltatasaink/webshop

Fichter, K. (2001). Environmental Effects of E-business and Internet Economy, First Insights and Environment-political Conclusions (pp. 10-11). Working Paper for the BMU, Berlin, August 2001. Retrieved

from https://www.borderstep.de/wp-content/uploads/2014/09/P-Fichter-Environmental_effects_of_e-business_an d_Internet_economy-2001.pdf

Forsyth, J., McGuire, T., \& Lavoie, J. (2000). All visitors are not created equal. McKinsey Marketing Practice. McKinsey \& Company, Whitepaper.

IVSZ. (2017). Szövetség a Digitális Gazdaságért: Indul a Digitális Jólét Program 2.0. Retrieved from http://ivsz.hu/hirek/indul-a-digitalis-jolet-program-2-0/

Jamsheer, K. (2019). Impact of e-Commerce on Society: Advantages and Disadvantages, eCommerce, Acowebs. Retrieved from https://acowebs.com/impact-ecommerce-society/

Javed, S. A. (2015). The impact of product's packaging color on customers' buying preferences under time pressure. Marketing and Branding Research, 2(1), 4-14. https://doi.org/10.33844/mbr.2015.60293

Knoke, F., \& Kovács, S. (2018). A (közel) jövő bevásárlóközpontja (pp. 28-30). Budapest: Chip. MediaCity Kft.

KSH as Központi Statisztikai Hivatal. (2018). Rendszeres internethasználók aránya Európában (2007-2018) a 16-74 éves személyek százalékában. https://www.ksh.hu/docs/hun/eurostat_tablak/tabl/tin00091.html

Laudon, K. C., \& Traver, C. G. (2015). E-commerce, Business, Technology, Society (11th ed.). USA: Courier Kendallville.

Liu, S. F. (2018). Evaluation of Outpatient Satisfaction and Service Quality of Pakistani Healthcare Projects: Application of a novel Synthetic Grey Incidence Analysis model. Grey Systems: Theory and Applications, 
8(4), 462-480. https://doi.org/10.1108/GS-04-2018-0018

Loveday, L., \& Niehaus, S. (2008). Web design for ROI, Turning Browsers into Buyers and Prospects into Leads. ISBN-13: 978-0321489821, Berkeley: New Riders.

Miniwatts Marketing Group. (2018). World Internet Useage and Population. Retrieved from https://www.internetworldstats.com/stats.htm

Nemeslaki, A., Duma, L., \& Szántai, T. (2004). E-business üzleti modellek (pp. 41-44). Budapest: ADECOM Kommunikációs Szolgáltató Rt.

Nielsen. (2014). Global E-commerce Report 2014. The Nielsen Company. https://doi.org/10.1155/2014/347043

Papows, J. (1999). Enterprise.com: Market Leadership. In The Information Age, An insider's guide to the IT revolution (pp. 153-195). Perseus Books Group Publishing, Washington. ISBN-13-9780738202266.

Peter, J. P., \& Olson, J. C. (2005). Consumer Behavior and Marketing Strategy (7th ed., pp. 481-514). New York: McGraw-Hill Irwin, ISBN: 0-07-286487-7.

PORTFOLIO. (2018). Aggasztó válság fenyegeti a világ legnagyobb gazdaságát. Retrieved from https://www.portfolio.hu/gazdasag/aggaszto-valsag-fenyegeti-a-vilag-legnagyobb-gazdasagat-innen-nehez-l esz-visszajonni.281010.html

Ryan, D. (2014). Understanding Digital Marketing (3rd ed.). London, UK.

Sadowski, B. B. (2000). The myth of market dominance: telecommunication manufacturing in Poland, Hungary and the Czech Republic: a case study. Telecommunications Policy, 24(4), 323-345. https://doi.org/10.1016/S0308-5961(00)00021-5

Syed, A. M. (2018). Perceived Organizational Performance and Trust in project manager and top management in Project-based organizations: Comparative Analysis using Statistical and Grey Systems methods. Grey Systems: Theory and Application, 8(3), 230-245. https://doi.org/10.1108/GS-01-2018-0009

Tari, K. (2016). Online fogyasztói szokások várható trendjei. In Közgazdász Kutatók és Doktoranduszok III. Téli Konferenciája - Tanulmánykötet, Doktoranduszok Országos Szövetsége - Közgazdaságtudományi Osztály (pp. 31-41).

Tari, K. (2017). Az Ipar 4.0 változásának hatásai: a versenyképességet javító tevékenységek és az ellátási lánc munkaköri változásainak tükrében. In Folyamat menedzsment kihívásai: Társadalmi-gazdasági fejlesztési irányok 2017 (pp. 159-176). Gödöllő. ISBN: 978-963-269-642-3. Retrieved from http://jadox.szie.hu/JaDoX_Portlets/displayContent?docId=15907\&secId=17324

Tiwari, S. (2011). E-Commerce: Prospect or Threat for Environment. International Journal of Environmental Science and Development, 2(3), https://doi.org/10.7763/IJESD.2011.V2.126

Valenduc, G., \& Vendramin, P. (2016). Digital Economy. 'Work in the digital economy: sorting the old from the new', European Trade Union Institute (ETUI), Brussels. https://doi.org/10.2139/ssrn.2770405

Virányi, P. (2014). Több mint reklámtörténelem. Budapest: Gondolat Kiadó.

\section{Copyrights}

Copyright for this article is retained by the author, with first publication rights granted to the journal.

This is an open-access article distributed under the terms and conditions of the Creative Commons Attribution license (http://creativecommons.org/licenses/by/4.0/). 